\title{
Szovjet fogságban volt egy amerikai ürkabin
}

\section{A BOILERPLATE ÜRHAJÓK}

Az ún. boilerplate - magyarul: kazánlemez - kifejezés 1959-től terjedt el az űrhajózásban, amikor egy amerikai űrhajót első ízben teszteltek egy vaslemezből készült makettel a különböző konfigurációk, alapméretek, rakományok és kezelési jellemzők vizsgálata céljából. A legelső modell valóban egy acélból készült kazánlemez-kapszula volt, amely a virginiai (USA) Portsmouthban, a norfolki haditengerészeti hajógyárban (NNSY - Norfolk Naval Shipyard) készült. A boilerplate kifejezést később azonban - átvitt értelemben az összes prototípuskapszulára használták. A modell - más néven tömegszimulátor - alkalmazása a valódi kabinnál jóval olcsóbb. A teljes méretű, de nem 100\%-os felszereltségű űrhajó építése költséghatékonyabb a komplett rendszer (tervezés, kipróbálás, újratervezés, indítás) megvalósításánál. A teszteredmények felhasználhatók többek között az űrhajó és a hordozórakéta összeillesztésénél, a vészhelyzeti megközelítésnél, a karbantartást segítő tevékenységnél és a különféle szállítási módozatoknál. A boilerplate űrhajókat leggyakrabban a személyzettel ellátott űrhajók próbáinál alkalmazzák. Az 1960-as évek elején a NASA, a Mercury ürhajó felbocsátásától kezdve a XXI. század második évtizedében megjelent Orion-programig, számos kísérletet végzett ilyen speciális modellekkel.

A technológiai Apollo-űrkabinok a BP-1-től BP-30-ig tartó sorszámozást kapták. A boilerplate-eket a szárazföldi és vízi becsapódás, valamint a visszatérő ejtőernyő vizsgálatára használták. A világürbe eljutott példányokon - mint pl. a BP-9-es - a mikrometeorok károsító hatásait tanulmányozták, míg a BP-29 jelűvel úsztatási kísérleteket végeztek. A BP-30-as használatára nem került sor, ez a modell az SM-15 és a LES-014 egységekkel kiegészítve, ma kiállítási tárgyként tekinthető meg a floridai Kennedy Ürközpontban (Kennedy Space Center).

A BP-1101 és BP-1302 közötti sorozatjelű űrkabinokat a tengeri kiképzéseknél alkalmazták, és ide tartozott a BP1227 lajstromszámú Apollo-űrkabin is.

\section{Az elveszett Apollo BP-1227 „MegtalálásA"}

Egy legenda szerint 1970 elején Nagy-Britannia partjainál a vízre szállást, és a vízből való mentést gyakorolták amerikaiak az Apollo-program keretében. Máig sem tisztázott körülmények között azonban - egy felületes magyarázat szerint - „a nagy ködben elvesztették” az Apollo BP-1227 CM-et (Boilerplate-1227 Command Module), azaz egy Apollo-űrhajó parancsnoki egységének méretarányos modelljét.

A valós tények felkutatása egy, Schuminszky Nándor asztronautikai gyűjteményében őrzött, 1970-ben készült felirata szerint: „Telefoto MTI Külföldi Képszolgálat” által közzé tett - és nyilvánosan publikált fotó nyomán kezdődött. A fotó képaláíása szerint: „Murmanszk. Átadták az Egyesült Államok képviselőjének az Apollo program keretében felbocsájtott kisérleti (sic.) kapszulát, amelyet szovjet halászok fogtak ki a Biscayai-öbölben". A képaláírásában szereplő „kísérleti kapszula” kifejezés egyértelműen vala-

\section{1. ábra. A híressé vált kép. Ez a fotó szerepel a témával kapcsolatos szinte valamennyi publikáció illusztrációjaként (Fotó: MTI archív)}

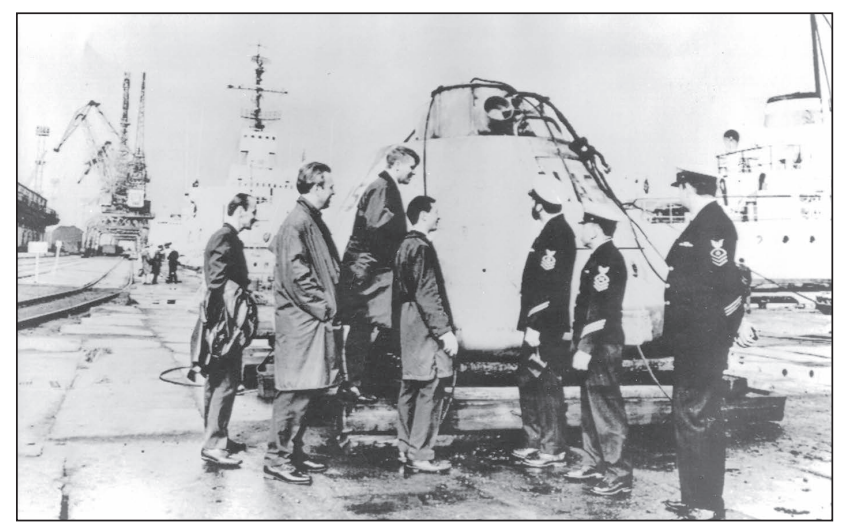

ÖSSZEFOGLALÁS: A szerzők a BP-1227-es lajstromszámú Apollo-űrkabinnal kapcsolatos korabeli események felkutatása nyomán annak a rejtélynek erednek nyomába, hogy 1970 elején az amerikai üreszköz miért és hogyan kerülhetett a szovjetek birtokába. A tanulmány kitér az ún. boilerplate ürhajók szerepére, a BP-1227-est fedélzetére emelő szovjet hadihajó történetére, és dokumentálja saját kutatómunkájuk fázisait. A szerzők kitérnek a tényfeltárást álhírekkel nehezítő sajtóorgánumok dezinformáló tevékenységére. A BP-1227 esete mögött konkrét példákkal idézik fel a szovjet-amerikai ürverseny különböző területeit: többek között a rádió-elektronikai harcot és a flotta-hadmúveleteket.

KULCSSZAVAK: Apollo-program, BP-1227 ürkabin, boilerplate ürhajó, Admiral Makarov, Westwind, Encyclopedia Astronautica
ABSTRACT: The authors, by searching for contemporary events related to the Apollo spacecraft with registration number BP-1227, reveal the mystery of why and how the American spacecraft may have fallen into Soviet possession in the early 1970s. The study covers the role of the so-called boilerplate spacecrafts, the history of the Soviet warship hoisting the BP-1227 on board, and prove the phases of their own research. The authors pad out about the misinformation of the press, which makes the fact-finding difficult with false news. Behind the case of BP-1227, specific examples are given of various areas of Soviet-American space competition, including radio-electronic combat and naval operations.

KEY WORDS: Apollo program, BP-1227 spacecraft, boilerplate spacecraft, Admiral Makarov, Westwind, Encyclopedia Astronautica

* Magyar Asztronautikai Társaság ORCID: 0000-0001-7947-8645

** Ny. orvos ezredes, c. egyetemi docens, Szegedi Tudományegyetem Általános Orvostudományi Kar Repülő- és Ürorvosi Tanszék. ORCID: 0000-0003-1715-1705 


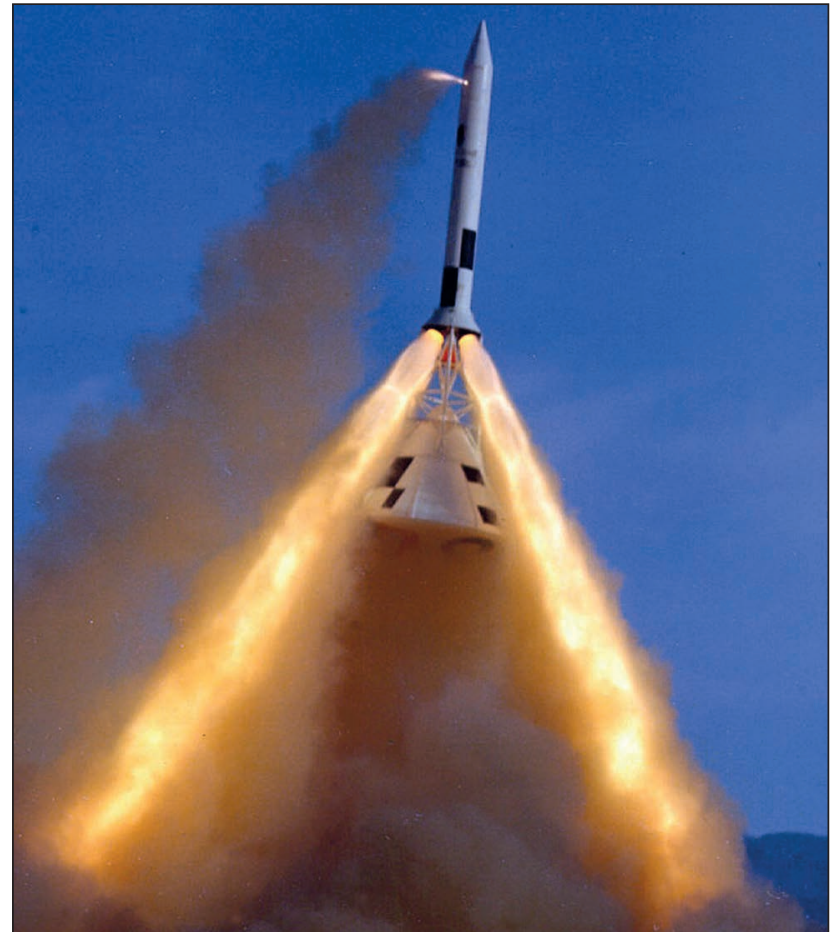

2. ábra. A mentőrakéta tesztelésénél is boilerplate ürkabint használtak (Fotó: NASA)

melyik Apollo BP-re utalt. Az 1964 és 1965 között, Saturn-I rakétákkal felbocsátott Apollo $\mathrm{BP}$ ürhajók nem tértek viszsza a Földre, hanem megsemmisültek a sűrübb légkörbe süllyedésük után. Teljes mértékben kizárható, hogy egy kísérleti ürkabin épségben leszálljon. A Spaceflight magazin 1974. áprilisi száma, a lap 137. oldalán felsorolja az Apollo-program űrhajóit és rakétáit, ezek között azonban nem szerepel a BP-1227-es. Az egyéb forrásokat kutatva is szembetűnő, hogy az Apollo BP-1227-es nemcsak „elveszett", hanem nyomtalanul eltűnt.

Az MTI-vel történt levélváltás során az MTI munkatársai megerősítették, hogy a kép valóban 1970. szeptember 8-án készült. Az Apollo-program akkor már túl volt két sikeres Holdra szálláson és egy balsikerü (Apollo-13) kísérleten.

A világhálón nyilvánosak a NASA Apollo-űrhajókra vonatkozó adatok, de a BP-1227-re utaló információ egy sincs közöttük. Schuminszky Nándor kutatóként a NASAhoz fordult, de érdeklődő e-mailjére nem kapott választ. A neves Apollo-szakértő, Richard Orloff, az Apollo a számok tükrében című könyv [6] szerzője sem tudott infomációt nyúitani az Apollo BP-1227-ről. (A kötetben csak az űrhajósokkal végrehajtott Apollo-repülésekről állított össze statisztikát.)

Fontos adalékot szolgáltatott Colin Burgess ausztrál szakíró a fotón látható tengerészek egyenruhájáról, amelyet amerikaiként azonosított. Ezzel bizonyossá vált, hogy amerikai hajóról van szó, és a tengerészek is biztosan amerikaiak.

\section{A HAJó, AMELY FEDÉLZETÉRE VETTE AZ ÜRKABINT}

A Wind osztályú hajókból összesen 8 db épült, az Amerikai Egyesült Államokban $7 \mathrm{db}$, és egy módosított változat Kanadában. A II. világháború alatt - az úgynevezett Lend-

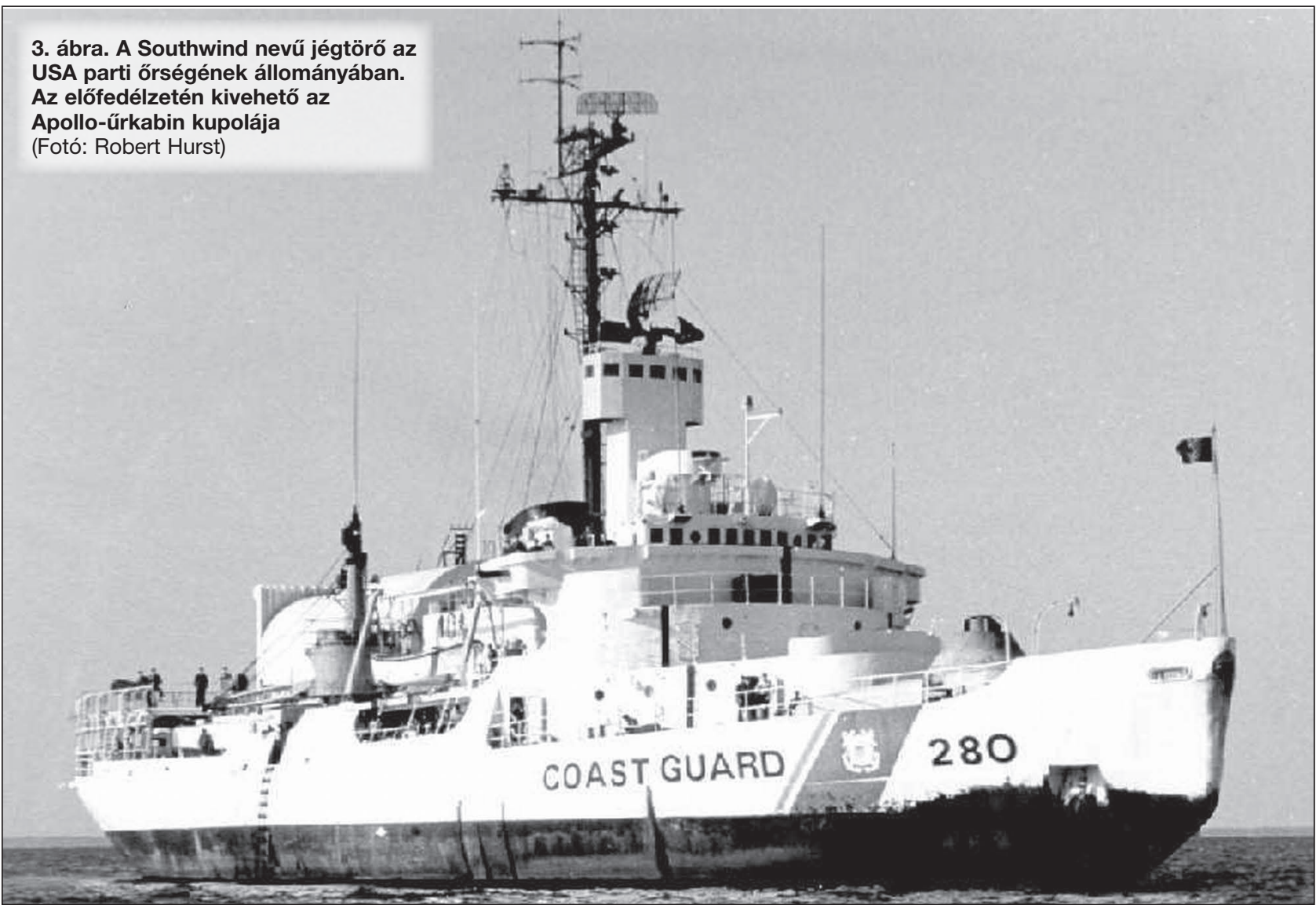




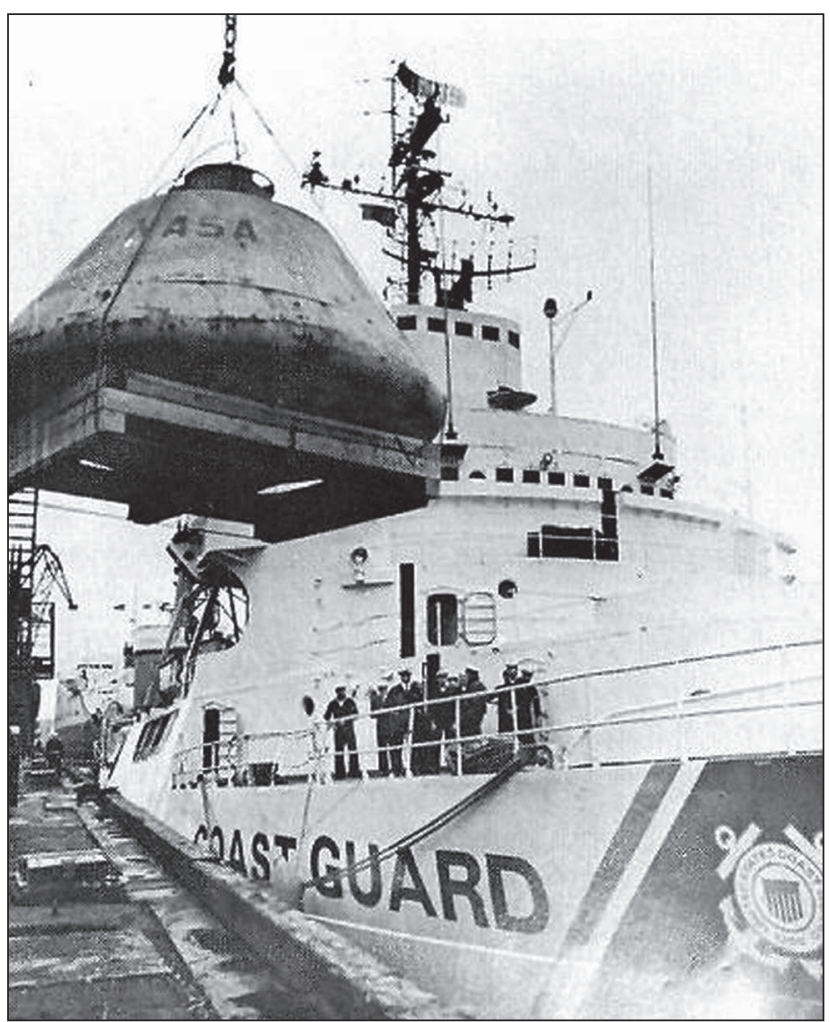

4. ábra. Beemelik az Apollo BP-1227-et a Southwind

fedélzetére (Fotó: astronautix.com)

lease (kölcsönbérleti) törvény alapján - az USA 3 db Wind osztályú jégtörőt adott át a szövetséges Szovjetuniónak. Az átadott hajók a Northwind (Északi szél), Westwind (Nyugati szél) és a Southwind (Déli szél) nevet viselték. A Szovjetunióban mindhárom hajót átnevezték; a Szevernij Vetyer (Северный ветер - Északi Szél), a Szevernij Poljusz (Северный Полюс - Északi Sark) és az Admiral Makarov (Адмирал Макаров - Makarov admirális) neveket kapták. Mivel az utóbbi hajó vette később a fedélzetére az Apolloűrkabint, a szerzők a továbbiakban csak ezzel a példánnyal foglalkoznak.

A hajógyárból frissen kikerült USCGC (WAGB-280) hajót, Southwind néven, 1944. július 15-én vették az Egyesült Államok Parti Örségének (The United States Coast Guard - USCG) állományába. 1945-től 1949-ig Admiral Makarov nevét viselve szolgált a Szovjetunióban, majd hazatérése után először az USS ATKA (AGB-3), majd ismét a USCGC Southwind nevet viselte.

1970 júniusa és novembere között személyzete oceanográfiai kutatásokat végzett a Barents- és a Kara-tengeren, egyúttal utánpótlást is szállított az amerikai sarki kutatóállomásoknak. Ezt követően látogatást tett Grönlandon, majd a hajónaplóban feljegyezhették a legészakibb meglátogatott pont koordinátáit: északi $83^{\circ}$ és $1^{\prime}$. Egy rövid izlandi látogatást követően a Southwind Murmanszkba hajózott. A II. világháború óta ez volt az első alkalom, hogy amerikai hadihajó érkezett szovjet kikötőbe. Az amerikai tengerészek meglepetésére a szovjetek közölték, hogy egy Apollo-űrkabint szándékoznak átadni számukra. Az átadás-átvétel megtörtént, és az Apollo BP-t a leszerelt első fedélzeti ágyú helyére rendben beemelték, majd a szovjet Vlagyimir jégtörő kíséretében a Southwind kihajózott a murmanszki kikötőből. (Ekkor a hajó fehér festésű volt, oldalán „Coast Guard 208” felirattal. Ez azért lényeges információ, mert egyes, a témával kapcsolatos írások illusztrá-

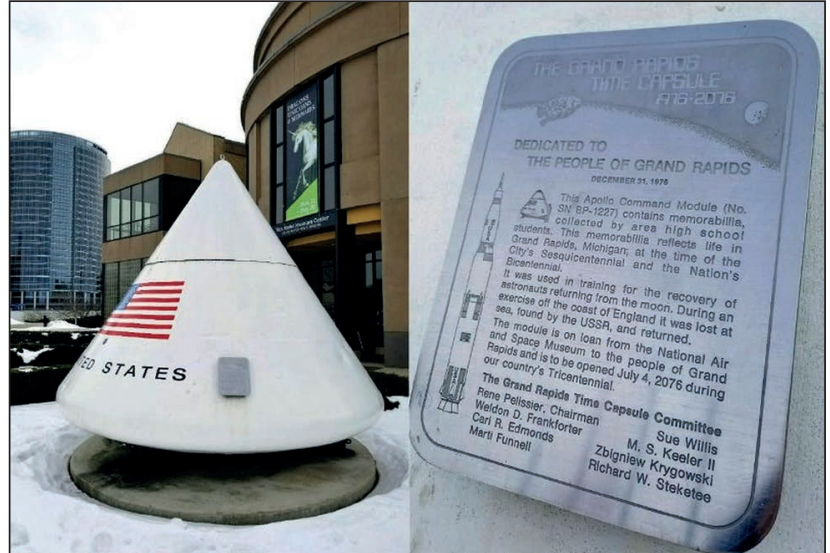

5. ábra. Az időkapszulává átalakított Apollo BP-1227 az emléktáblával (Fotó: Vincze Miklós)

cióin helytelenül, egy fekete festésű Wind osztályú hajó szerepel).

A Southwind A Szovjetunióból Norvégia felé vette az irányt, előbb Tromsø, majd Oslo partjainál kötött ki, végül az angliai Portsmouth kikötőjébe hajózott. Ott az űrkabint átrakták a Royal Navy (Angol Királyi Haditengerészet) egyik hajójára, amely az Apollo BP-t az USA Maryland államának partjára szállította. A NASA átvette az eszközt és az érdeklődők számára Washingtonban, a Smithsonian Intézetben állította ki. Az űrkabint 1976-ban, az Egyesült Államok bicentenáriumi ünnepségeinek keretében a Michigan állambeli Grand Rapids-ba szállították, ahol egyfajta időkapszulaként állították ki, és a korszakra jellemző emléktárgyakat helyeztek el benne. Felnyitását 2076. július 4-én, az Egyesült Államok megalakulásának 300 . évfordulóján tervezik. (5. ábra)

\section{FELGYORSULÓ KUTATÓMUNKA}

A BP-1227-es történetének felkutatása érdekében Schuminszky Nándor az egyik legjobb űrhajózási adatbázist működtető szakemberhez, Mark Wade-hez fordult. (A tudós Encyclopedia Astronautica nevű adatbázisa napjainkban is elérhető, sőt időközben egyesült a Günter's Space Page-dzsel [6].)

Mark Wade hatalmas önálló felületet nyitott a keresésnek, és élő szemtanúk, érdemben hozzászólók jelentkezését is várta. Adam Bootle emlékezni vélt egy elveszett Apollo-űrkabinra, és ezt a tényt egy John Charles nevü hozzászóló is megerősítette. A kutatók számára nagy meglepetést jelentett a magyar Fehér Tamás észrevétele a magyar Ûrhajózási Lexikon 33. oldalán látható képről. [4] A kép alatti szöveg szerint egy üres Apollo-kabint emelnek ki a tengerből, de ez az információ nyilvánvalóan ellenkezik a valósággal. A háttérben lévő egyszerű épületek - inkább Murmanszk kikötőjére emlékeztetnek - erősítette meg Fehér Tamás.

Egyre többen bekapcsolódtak az Apollo-rejtély részleteinek felderítésébe. Az internet megkönnyítette a kapcsolattartást, és látványossá vált, hogy a világ számos pontján sok ember mozdult meg a kérdés megválaszolása érdekében.

A szakemberek és amatőr érdeklődők mellett a bulvár média is bekapcsolódott a helyzet kommunikációjába. Azt híresztelték, hogy az amerikaiak az Apollo-13 esetében nem akartak a Holdra repülni, csak megtévesztésből rendezték meg a startot, ami valójában egy ember nélküli, 
szuborbitális repülés volt. Az űrkabin a tengerre való leszállás után került a szovjetek kezébe, és ezt adták vissza a nemzetközi üregyezménynek megfelelően. Ez természetesen nem volt igaz, és továbbra is nyitva maradt a kérdés, hogy hol, mikor és hogyan került a Szovjetunióba az Apollo BP-1227-es ürkabin.

A hivatalos magyarázat szerint „szovjet halászok találtak, és kihalásztak egy űrkabint a Biscaya- (Vizcayai)-öbölben”. Ezt az állítást, minden bizonnyal a korabeli hivatalos változat részének kell tekinteni, mert az információk és a dezinformációk harca a hidegháború velejárója volt.

\section{ÁLHÍrEK ÉS TÉNYEK}

A XXI. század első évtizedére az Apollo BP-1227 története nemcsak bekerült a legismertebb űresemények közé, hanem szilárdan tartja a helyét az Encyclopedia Astronautica oldalán. Az eseménnyel kapcsolatos fake news-ok sorát az Orbit nevű, űrkutatási bélyegekkel foglalkozó szaklap nyitotta meg. (6. ábra) 2011. júniusi számának 21. oldalán ezt írta: "The capsule has been recovered by an Hungarian fisheries ship" (Az ürkabint egy magyar halászhajó szállította [Murmanszkba]). Ezt követően a Spaceflight magazin 2016 áprilisában a 148. oldalon erre még rálicitált: „...the capsule was picked up by a Hungarian trawler and handed over to the Russians" (Az űrkabint egy magyar vonóhálós halászhajó halászta ki, és adta át az oroszoknak) (7. ábra).

Az Apollo BP-1227 története egy orosz nyelvű oldalon is felbukkant. A Deseret News 1970. szeptember 4-én „szovjet halászok"-ról írt. A The Stars and Stripes szintén szovjet halászokat említ, de ha megnézzük az 1970. szeptember 6-i dátumot és az alatta lévő fotót, akkor felismerhetjük a hátán az egykori fotóalbum matt fekete oldalát. Rejtély, hogy ez az utánozhatatlan fotó miként kerülhetett rá egy évtizedekkel korábbi lapra. A UPI híre szerint az ürkabin

6. ábra. Az Orbit űrkutatási bélyegekkel foglalkozó szaklap 2011. júniusi számának a 21. oldalán közölt cikk kinagyított szövegrészlete

time and after that, in September 1970, made for the Soviet harbour of Murmansk.

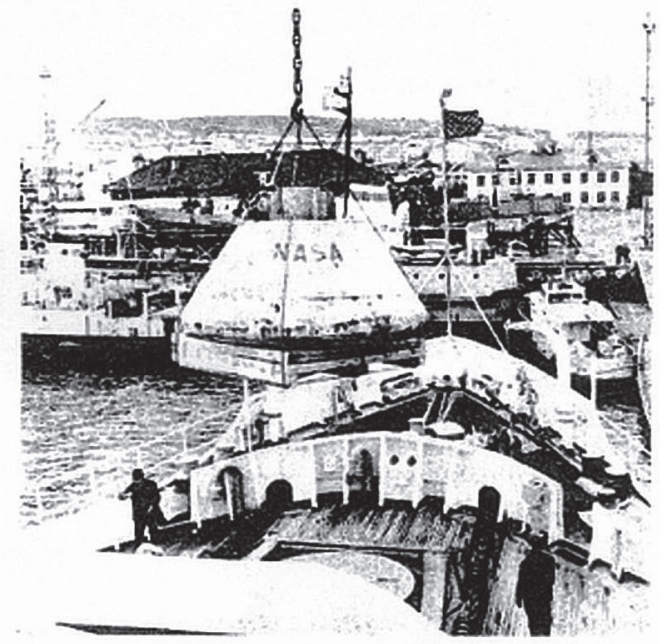

To their immense surprise in that harbour the Americans observed the capsule that they had lost about a year before. The capsule had been recovered by an Hungarian fisheries ship. As part of the Nixon-Kissinger-Brezhnev détente

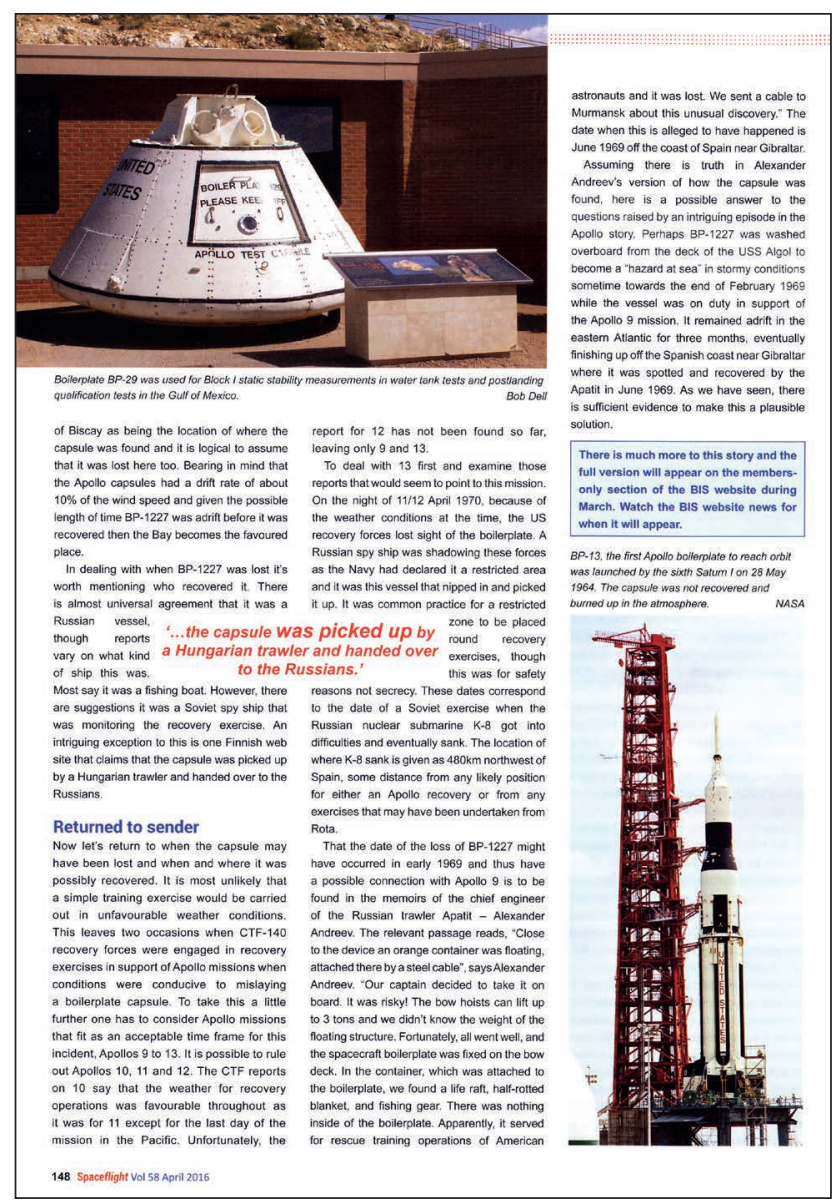

7. ábra. A Spaceflight magazin 2016 áprilisában a 148. oldalon, piros betükkel közölte: „....the capsule was picked up by a Hungarian trawler and handed over tot he Russians."

1968-ban veszett el, tehát több mint egy évig volt szovjet „fogságban”. (8. ábra) A magyar Népszabadság csak a visszaadás tényéről számolt be, meglehetősen szűkszavúan, de tényszerüen.

2016-ban, a BP-1227-es történetének elindítóit e-mailben megkereste Vitalij Naszennyik orosz fizikus: „Tulajdonképpen engem csak érintölegesen érdekelt a BP-1227 átadásáról 1970 szeptemberében, Murmanszkban készült fénykép. Az esemény körül sok minden tisztázatlan. Nem ismert, ki és mikor készítette ezt a képet. Egyes források azt állitják, hogy szeptember 6-án, mások szerint szeptember 8-án. A képet először 1970. szeptember 9-én publikálták, az amerikai Tipton városkában (Indiana állam) megjelenö Tipton Daily Tribune újságban [5]. Képaláírásként TASS PHOTO VIA UPI szerepel. 1970. szeptember 4-én számos amerikai kiadvány - hivatkozva a UPI-on (United Press International) keresztül kapott TASZSZ közleményére - adott hirt az ürkabin várható átadásáról. A probléma csak az, hogy ilyen TASZSZ-közlemény egyetlen szovjet újságban, sem a rádióban, sem a televízióban nem jelent meg. Nem található abban a TASZSZ archívumban sem, amelyet megőrzésre az Orosz Föderáció Állami Levéltárának adtak át. Hivatalosan megkerestem őket, de azt válaszolták nekem, hogy ilyen dokumentumot nem öriznek." (Dr. Remes Péter fordítása)

Naszennyik úr levele azért is érdekes, mert Oroszországban már korábban napvilágot láttak az Apollo BP-1227esről szóló hírek. Először 2007-ben hozták nyilvánosságra, hogy az űrkabint az Apatit (9. ábra) nevű vonóhálós halász- 


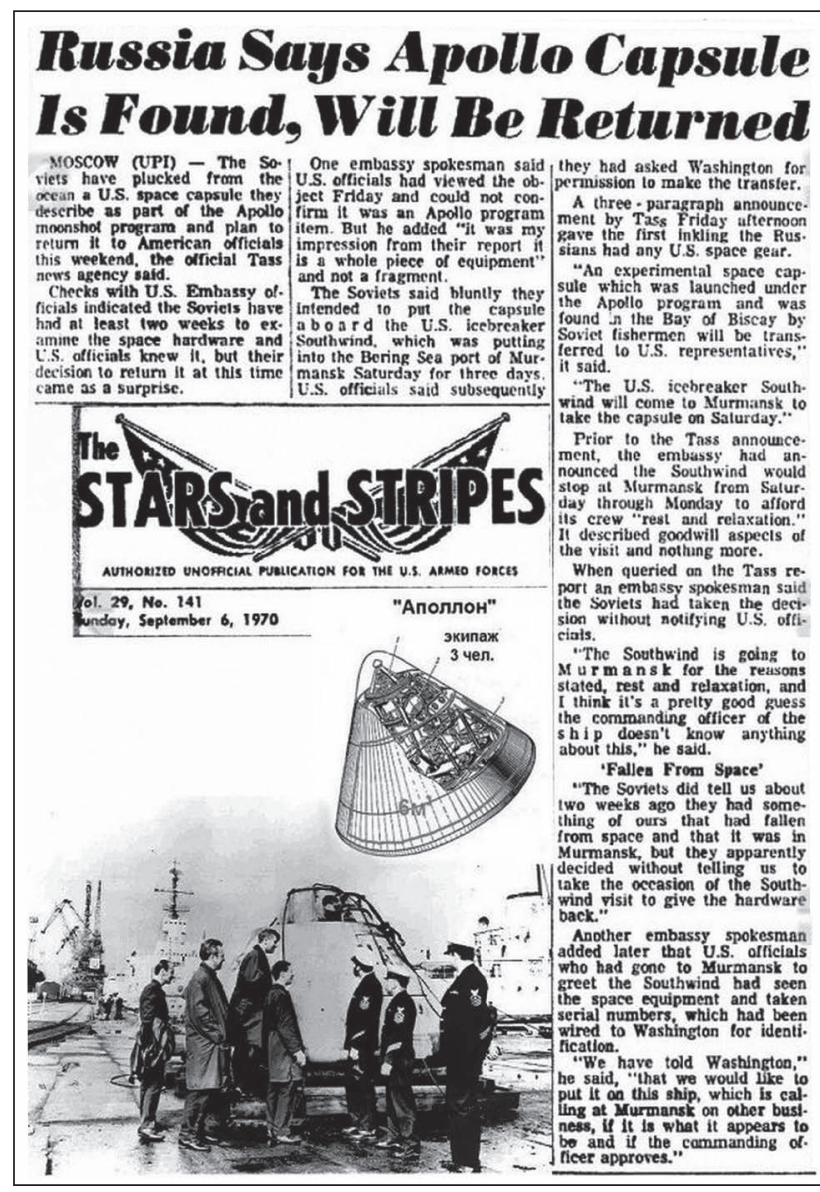

8. ábra. The Star and Stripes, 1970. szeptember 6. [5]

hajó találta meg. Ennek a hajónak a főmérnöke Alekszandr Andrejev volt, akinek emlékiratát Dmitrij Jermolajev adta közre a Murmanszki Komszomolszkaja Pravdában. A második híradás 2014. november 29-én történt, a harmadik pedig 2015. február 28-án, a Murmanszki Közlönyben. Ekkor képet is közöltek az Apatit kapitányáról, Ivan Sanykovról. „A készülék (ürkabin) közelében egy narancssárga tartály lebegett, acélkábellel rögzítve - írta Alekszandr Andrejev. - A kapitányunk úgy döntött, hogy felveszi a fedélzetre. Kockázatos volt! Az ijemelöink akár 3 tonnát is fel tudnak emelni, de a vízen lebegő szerkezet súlyát nem tudtuk. Szerencsére minden jól ment, és az ürhajót sikerült rögzíteni a fedélzeten. A hozzá rögzített tartályban mentötutajt, félig rothadt takarót és halászeszközöket találtunk, de az ürkabin belsejében semmi sem volt. Nyilvánvalóan az amerikai ürhajósok mentési kiképzéséhez szolgált és valahogyan elveszett. Táviratot küldtünk Murmanszknak erröl a szokatlan felfedezésröl."

Andrejev az emlékirataiban állítja, hogy az Apatit kapitánya, Ivan Sanykov a KGB-től egy vadászpuskát kapott jutalomként a felfedezéséért, és az ürkabin megszerzéséért, mert, ahogy a hatóságok fogalmaztak: „... érdekes és fontos” volt. Az esemény dátumaként 1969. júniusát jelölte meg, a megtalálási hely azonban nem Anglia, hanem Spanyolország partjainak közelében volt. Ez a helyszín azonos a Franciaország nyugati és Spanyolország északi partja mentén elterülő a Vizcayai-öböllel, amely az Atlanti-óceán részét képezi.

Megjegyzendő, hogy ha az űrkabint Murmanszkba szállították, azt nem tehették volna meg a szovjet északi flotta értesítése/beavatkozása nélkül. Ráadásul egyetlen szovjet halászhajó sem emelhette volna a fedélzetére a NASA felirat láttán, de még inkább Moszkva engedélye nélkül. Nyilvánvalóan Moszkva sohasem mondott volna le egy ilyen „ölébe hullott kincs"-ről. Az említett időszakban a Szovjetunió flottatevékenysége nem nélkülözhette a rádiófelderítő hajók jelenlétét; a felderítő hajók egy csoportja ott volt a közelben, természetesen álcázva. A hajótest kialakítása halászhajó jellegű volt, fedélzetükön a legénység polgári ruhában teljesített szolgálatot. Nagy valószínűséggel ők szerezték meg az Apollo-űrkabint.

A szovjetek kezére került űrkabint a szakemberek alaposan áttanulmányozták. A Holdra szállás elsőségéért folytatott versenyben ekkor már javában folytak a szovjet kísérletek. $A z$ amerikai eredmények kézzel fogható terméke valóban nagy haszonnal kecsegtetett a szovjetek számára, és így lett volna fordítva is, ha az amerikaiak tudtak volna megkaparintani egy szovjet űrhajót, esetleg annak valamilyen technológiai példányát, modelljét.

„Ez egy nagyon gondosan megmunkált, vastagon cinkkel borított, fémből készült ürkabin volt, minden látható korrózió nélkül. Minden határtalanul egyszerü volt. Mindössze a keresö-fényjelző rendszer volt komplett, vagyis teljes értékü, és a hővédő pajzs is eredetinek bizonyult" - írta jelentésében Viktor Blagov, a szovjet katonai szállító-ellátó űrhajó (TKSZ) egyik tervezőmérnöke. A szovjet holdűrhajó (LOK) tervezőmérnökeit a Misin-intézetből (CKBEM - Központi Kísérleti Gépgyártási Tervezőiroda), a TKSZ mérnökeit pedig a Cselomej-intézetből (CKBM - Központi Gépipari Tervezőiroda) azonnal Murmanszkba rendelték, hogy sürgősen és alaposan tanulmányozzák át a birtokukba került eszközt. Először is azonosították, hogy a szóban forgó űrkabin méretre és tömegre megegyezik az Apollo parancsnoki moduljával (CM). Ezután sajnálattal állapították meg, hogy a fényjelző berendezésen kívül semmi sem teljes értékű, minden egyéb csak a gyakorlás céljainak megfelelő technológiai imitáció. Mégis értékes információhoz jutottak az űrhajó fémszerkezetének, anyagának, ötvözetének és megmunkálásának megismerésével. A szovjetek kezére jutott az eredeti optikai rendszer és az űreszköz ablakrögzítésének technológiai megoldása is.

A tanulmány szerzői a 2010-es években ismét kísérletet tettek az MTI-nél, hogy pontosabb információkhoz jussanak. Az újabb válasz sem tartalmazott a korábbinál pontosabb információkat:

„...A fotó, ... az MTI Képes Híradó egy példánya, mely akkoriban (1970) hetenként jelent meg és a legaktuálisabb sajtófotókat mutatta be a nagyközönségnek. A képet nem az MTI munkatársa készítette, hanem része volt a megállapodásokon alapuló nemzetközi tájékoztatási láncnak, amelynek aktív része az MTI évtizedek óta. A fotó a TASZSZ szovjet hírügynökség révén járta be a világsajtót, így közöltük mi is. Az amerikai kísérleti „ürkapszulát”, ahogy fotó kísérőszövegén is olvasható a szovjet hatóságok szolgáltatták vissza. A kép eredeti - angol nyelvü - szövegének fordítása korrekt. Érdekessége, talán annyi lehet, hogy mit kereshettek szovjet halászok a Biscayne (sic!) öbölben Murmanszktól óriási távolságra, és hogy került oda az átadott ürhajóalkatrész (?). A történetről elérhető egy, s más az interneten, de a nálunk archívált fotóból sajnos több nem derül ki."

\section{RÁDIÓ-ELEKTRONIKAI HARC}

A verseny nemcsak a világürben, hanem a Földön is kíméletlenül folyt a nagyhatalmak között. Az átlagember talán nem is sejtette, hogy a Hold eléréséért való küzdelemnek katonai vonatkozásai is voltak. 


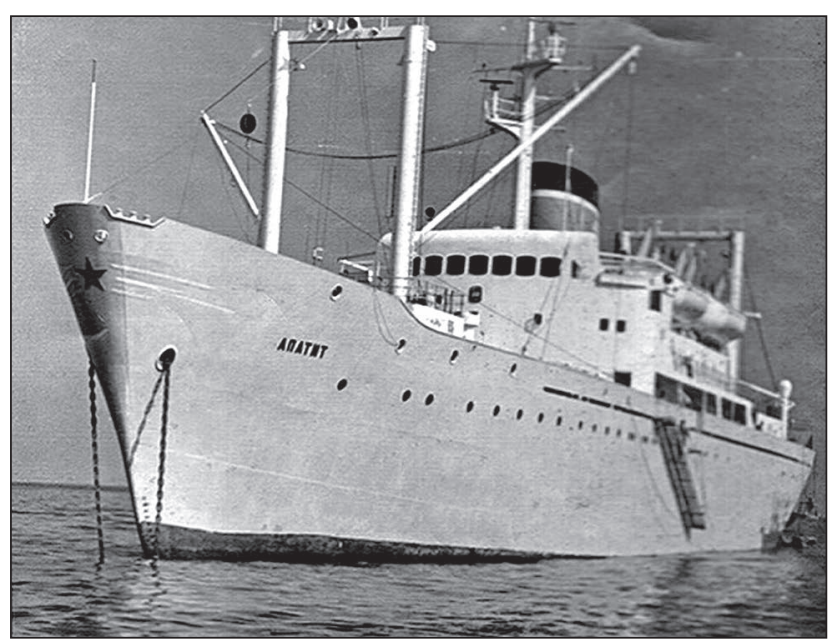

9. ábra. Az Apatit elnevezésű „halászhajó”, az állítólagos megtaláló (Fotó: astronautix.com)

Amikor az amerikaiak elindították a Holdra az Apollo-11et, akkor a szovjet rádió-felderítőket azonnal harckészültségbe helyezték. Válaszul az amerikaiak ugyancsak hajórajokkal vették körül a létszámfölényben lévő szovjet rádiófelderítő hajókat, és masszív rádiózavarással akadályozták a szolgálati forgalmazás lehallgatását. A művelethez nagy erőket kellett bevetni. Alulról tengeralattjárókkal, felülről pedig harci repülőgépekkel biztosították a helyzetet. Ezek a manőverek anyagi-technikai és logisztikai feladatokat igénylő hidegháborús hadműveletek voltak, a hadművészet története is így tartja számon azokat.

\section{FLOTTA-HADMÜVELETEK}

Az amerikai rakétaindítások dátumait, időpontjait, mint pl. az Apollo-13-ét elöre bejelentették. Azokban a napokban a Szovjetunió a világ egyik legnagyobb tengeri hadgyakorlatába kezdett. Az „Okean” (Óceán) fedőnevű, globális hadgyakorlatban több száz szovjet hadihajó vett részt. 1970. április 11-én, az Apollo-13 startnapján, a Szovjetunió Hadiflottája úgy foglalta el pozícióit az Atlanti-óceánon, hogy megszállta az előre kijelölt kényszerleszállási, és a várható leszállási körzeteket is. El akarták fogni az ürhajót vagy az űrhajósokat, de még jobb lett volna számukra, ha az űrkabint az utasaival együtt szerzik meg. Ezt hívják a hadművészetben hadászati célnak. A hadműveleti cél pedig az erődemonstráció, és a hadászati együttműködés gyakorlásán kívül az ellenséges űrtevékenység felderítése volt, az ellenséges űreszközök és űrhajósok megszerzése útján. Ezekben az években a nemzetközi ürjogban az a furcsa helyzet állt elő, hogy az USA nem szállhatta meg (nem foglalhatta el) az orosz leszállási körzeteket, mert ezek szovjet felségterületen, a szárazföldön voltak. A Szovjetunió azonban megszállhatta (elfoglalhatta) az USA űrhajók leszállási körzeteit, mert azok nemzetközi vizeken voltak.

Az ellenséges flották között a helyzet kezdett tarthatatlanná válni, végül a Szovjetunió és az Egyesült Államok egyezményt kötött. A Holdért való küzdelemben ugyanis eljutottak arra a pontra, hogy megértették: bármelyik ország ürhajója érkezik vissza a Hold körzetéből, nagy a valószínűsége annak, hogy ellenséges kezekbe kerül. Ezért lemondtak egymás úreszközeinek elfogásáról, és megállapodtak, hogy vészhelyzetben is csak abban az esetben nyújtanak egymásnak segítséget, ha azt a másik fél kifejezetten kéri. Az egyezmény természetesen a tengeralattjá- rókra is vonatkozott, és ezért nem foghatták el az amerikaiak például a sérült $\mathrm{K}-8$ atom-tengeralattjáró személyzetét.

A NATO-kód szerinti November osztályú K-8-as balesete 1970. április 11-én, az Apollo-13 startjának napján történt. A tengeralattjáró a Földközi-tengeren hajózott, ahol járőrözési harci feladatot látott el, amikor az Óceán-hadmúvelet miatt visszatartották, és új parancsot kapott; vegyen részt az észak-atlanti manőverekben, ezért még a Földközi-tengeren új ellátmánnyal látták el, feltöltve a készleteit. Április 8-án váratlanul tűz ütött ki a vezérlőegységben, és gyors terjedése következtében a tengeralattjáró irányíthatatlanná vált. $A$ sűrü füst és a tűz elzárta egymástól a tengerészek különböző csoportjait, de néhányuknak - saját életük feláldozása árán - sikerült leállítaniuk az atomreaktort, megelőzve a robbanást. A többiek - sérüléseik következtében - súlyos sugárbetegséget szenvedtek, de még így is sikerült a K-8-asnak a felszínre emelkednie. A sietve odaérkező hadihajóknak az lett volna a feladatuk, hogy a sérült atom-tengeralattjárót vontatókötélre vegyék, és egy hazai kikötőbe vontassák. A térségben tomboló erős vihar miatt, a többszöri próbálkozás után sem sikerült a mentés, ezért a manővert másnapra halasztották. Április 12-én 6:13-kor azonban a Kaszimov hadihajó szolgálatban lévő másodtisztje azt jelentette, hogy vörös rakétát látott a K-8-as irányából. A lokátor képernyőjén pedig egy néhány másodpercig tartó erősödő felvillanás után, a tengeralattjáró radarjele eltűnt. A K-8 tengeralattjáró elsüllyedt atomreaktorostól, atomtöltetű torpedóival, a legénység hátramaradt részével és a kapitányával együtt.

A katasztrófa hírére az amerikai haditengerészet erői elhagyták harcászati, ügyeleti körzeteiket, és erős aktivitást mutattak a bajba jutott szovjet tengeralattjáró körül. Abban reménykedtek, hogy a legénység megadja magát és segítséget fog kérni tőlük. Akkor pedig jogszerűen zsákmányolhatnak egy értékes orosz tengeralattjárót teljes személyzetével, atomreaktorával, nukleáris torpedóival, és az éppen zajló hadművelet minden titkos anyagával együtt. Ez alapos indok lehetett arra, hogy az amerikaiak eltávolodjanak a gyakorlatozó Apollo-űrkabintól, és a K-8-as tengeralattjáró körzetébe siessenek. A magára hagyott Apollo-űrkabint ekkor kaparinthatta volna meg egy szovjet hajó, esetleg tengeralattjáró

A szovjet felderítő jelentések szerint a BP-1204-est tengeri kiképzésre például a spanyol Rota kikötőjénél alkalmazták, a BP-1215 a japán Jokoszuka tengerészeti bázis közelében, a BP-1223 pedig az Azori-szigetek térségében tűnt fel. Valószínű, hogy a BP-1227-est a Franciaország nyugati és Spanyolország északi partja mentén elterülő Vizcayai-öbölben valóban használták az amerikaiak, de hogy az „elveszett” űrkabint „szovjet halászok” fogták volna ki a tengerből az Apollo-13 leszállási körzeteiért vívott hidegháborús szovjet-amerikai flottahadműveletek kellős közepén, ez minden bizonnyal csupán a legenda része.

\section{ELTITKOLT MINI-ÜRREPÜLŐGÉPEK}

Természetesen az amerikaiak is - minden lehetséges alkalommal - komoly erőket mozgósítottak a szovjet űreszközök megszerzése érdekében. Ez történt például a BOR-4 nevű, 1:2 méretarányú mini-űrrepülőgép kísérleti repüléseinél is. Egy szuborbitális és négy orbitális kísérletnél alkalmazták ezt az űreszközt, a hiperszonikus elfogó-vadász űrrepülőgépek, valamint a későbbi szovjet űrrepülőgéphez, a Buranhoz használandó hőálló bevonatok teszteléséhez.

A BOR kísérleti repülései 1980 és 1983 tavasza között titokban folytak. 1983. március 15-én, a 403-as gyári számú 


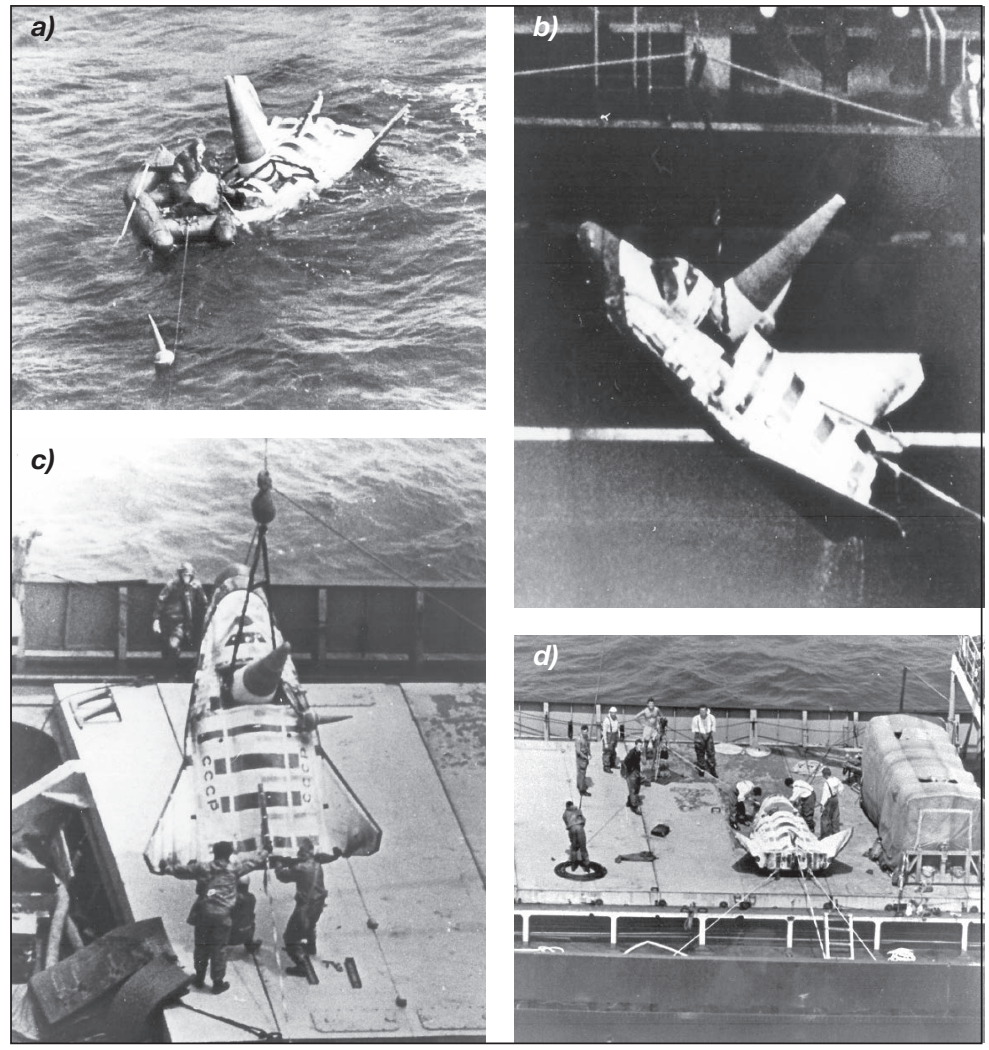

10. ábra. Az ausztrál légierő egyik P-3 Orion típusú felderítő gépe lefényképezte a Kozmosz-1445 néven lajstromozott, visszatért BOR-4 mini-ürrepülőgépet. A fázisképeken a kiemelés látható (Fotók: Royal Australian Air Force)

példány másfélszer kerülte meg a Földet. A Föld légkörébe belépő manőverező mini-űrrepülőgép leszállása körzetében sikeresen végrehajtott egy 600 km-es oldalirányú manővert (erre tervezték). A visszatérés alatt a BOR-4-essel a Volkov Ürhajós és a Beljajev Ürhajós nevű hajókról tartották a rádiókapcsolatot. A mini-űrrepülőgép ejtőernyővel sikeresen leszállt a vízre, a szovjet hadiflotta védelmében. Ezúttal azonban az amerikai hadiflotta mellett az Ausztrál Királyi Légierő egyik P-3 Orion típusú felderítő repülőgépe is a leszállás körzetében őrjáratozott, és így az események nem maradhattak titokban. Fényképfelvételekkel és a rádióirányítás teljes anyagának lehallgatásával, részletes felderítési anyag készült a Kozmosz-1445 lajstromszámú, BOR-4 típusú mini-űrrepülőgép mentéséről (10. ábra).

A szovjetek az ellenséges manőverektől zavarva emelték fel a BOR-4-est a Petropavlovszk nevű hajó fedélzetére. A szovjet kutató-mentő csapatok tengerészeinek beszámolói szerint az ausztrál repülőgép olyan intenzív „rácsapásokat” hajtott végre a Petropavlovszk fedélzetére, hogy a légörvények csaknem leverték a lábukról a fedélzeten dolgozó tengerészeket. Az ellenséges légi zavaró repülés és a hullámzó tenger mellett, egy rosszul felkészített legénység könnyen elveszthette volna az üreszközt. $A$ jó kiképzés minden esetben sikert hozott, a mini-űrrepülőgépek nem kerültek ellenséges kezekbe. A használható felvételek azonban bizonyították, hogy a szovjetek is előrehaladott állapotban tesztelik a szárnyas, többször felhasználható üreszközeiket.

Az ellenséges felderítés kiküszöbölése érdekében, valamint a rádiótechnikai irányítás fejlődésének következtében a további BOR-repülések leszállókörzetét a Fekete-tengerre jelölték ki. Az utolsó BOR-4 leszállásánál (Kozmosz-1614, 1984. december 19.) azonban mégis becsúszott egy irányí- tási hiba, és a Szevasztopoltól nyugati irányban vízre szálló mini-űrrepülőgépet - a hivatalos közlés szerint - „nem sikerült megtalálni”.

Az Apollo BP-1227 ürkabin története jól példázza, hogy a hidegháború időszakában a nagyhatalmak között globális méretekben zajlottak katonai múveletek; földön, vízen, víz alatt, levegőben és az űrben. A közvélemény „tájékoztatásakor" békés célú űrkutatásként említett űrtevékenység mögött, valójában kíméletlen küzdelem zajlott.

Az enyhülés kezdetekor, 1971-ben a CIA a szovjet űrprogram nemzeti hírszerzési becsléséről szóló jelentésben kijelentette: „Az USA szinte minden korábbi erőfeszítése, hogy a szovjeteket kooperatív vagy közös ürprogramokba való bevonására ösztönözze, korlátozott sikerrel járt". A jelentés megemlíti, hogy 1970 októberében, egy hónappal a BP-1227 visszatérése után, megbeszélések kezdődtek a kompatibilis szovjet és amerikai űrrandevú és öszszekapcsoló rendszerek kívánalmáról. Innen vezetett az út az 1975-ös első közös szovjetamerikai űrrepüléshez. [1]

Az Apollo BP-1227 ürkabin történetének kutatása Schuminszky Nándor számára jelentős szakmai elismerést hozott. A Haditechnika folyóirat űrrovatának állandó szerzője, a történet felderítésével bekerült az Encyclopedia Astronautica Who is Who in Space? rovatába (a szerk.). [2] [3]

\section{HIVATKOZOTT IRODALOM}

[1] Remes Péter, Apollo ürkabin egy szovjet hadikikötöben. Kézirat;

[2] Encyclopedia Astronautica - „Hungary” http://www. astronautix.com/h/hungary.html;

[3] Encyclopedia Astronautica - „Schuminszky” http:// www.astronautix.com/s/schuminszky.html;

[4] Ürhajózási Lexikon, Budapest: Akadémiai Kiadó-Zrínyi Katonai Kiadó, 1981.;

[5] NewspaperArchive.com, „Tipton Daily Tribune Archives, Sep 9, 1970, p. 11" https:// newspaperarchive.com/tipton-daily-tribune-sep-091970-p-11/;

[6] Richard Orloff, Apollo By The Numbers - A Statistical Reference, NASA No.: SP-2000-4029, Washington DC: NASA History Division, 2000. https://history.nasa. gov/SP-4029.pdf.

\section{A CIKKBEN SZEREPLŐ RÖVIDITÉSEK}

BP - boilerplate - több-kevesebb valódi felszereléssel, berendezéssel ellátott, 1:1 méretarányú űrhajómodell.

BOR - БОР, Беспилотный Орбитальный Ракетоплан - pilóta nélküli orbitális rakéta-űrrepülőgép.

CIA - (Central Intelligence Agency - Központi Hírszerző Ügynökség).

CM - Command Module - parancsnoki egység vagy modul,

Apollo-űrkabin

SM - Service Module - műszaki egység vagy modul.

LES - Launch Escape System - mentörendszer.

LOK - Lunnij Orbitalnij Korabl (Лунный Орбитальный Корабл) - Hold körül keringő űrhajó, holdűrhajó.

TKSZ - Transzportnij Korabl Sznabzsenyija (Транспортный корабль снабжения) - szállító-ellátó űrhajó.

NASA - National Aeronautics and Space Administration - Nemzeti Repülési és Ürhajózási Hivatal 